Article

\title{
Analysis of the Long-term Precipitation Trend in Illinois and Its Implications for Agricultural Production
}

\author{
Vaskar Dahal, Sudip Gautam ${ }^{(D)}$ and Rabin Bhattarai * (D) \\ Department of Agricultural and Biological Engineering, University of Illinois at Urbana-Champaign, \\ Champaign, IL 61801, USA; vdahal2@illinois.edu (V.D.); sgautam3@illinois.edu (S.G.) \\ * Correspondence: rbhatta2@illinois.edu
}

Received: 16 March 2018; Accepted: 4 April 2018; Published: 6 April 2018

\begin{abstract}
Climate change is expected to modify the hydrological cycle resulting in a change in the amount, frequency, and intensity of surface precipitation. How the future hydrological pattern will look is uncertain. Climate change is expected to bring about intense periods of dryness and wetness, and such behavior is expected to be difficult to predict. Such uncertainty does not bode well for the agricultural systems of the United States (US) Midwest that are reliant on natural precipitation systems. Therefore, it is necessary to analyze the behavior of precipitation during the cropping period. The manifestation of global-warming-related changes has already been reported for the last couple of decades and more so in the current decade. Thus, precipitation data from the recent past can provide vital information on what is about to come. In this study, the precipitation data of Illinois, a Midwestern state of the US with rain-fed agriculture, was analyzed with a focus on the climate dynamics during the cropping period. It was observed that even though there has been some increase in the annual precipitation amount $(+1.84 \mathrm{~mm} /$ year $)$ due to the increase in precipitation frequency and intensity, such change happened outside of the cropping period, thereby ensuring that climate change has not manifested itself during the cropping period.
\end{abstract}

Keywords: climate change; rain-fed agriculture; cropping period; extreme events; Midwest

\section{Introduction}

According to the fifth assessment report of the Intergovernmental Panel on Climate Change (IPCC), the last three decades on Earth have been increasingly warmer than the previous decades [1]. The report also states that on a global scale, the troposphere has warmed, whereas the lower stratosphere has cooled since the 1950s. Climate change affects the hydrological cycle, which results in frequent floods, droughts, and other abnormalities on the Earth's surface. It also affects the stationarity of climatic variables, such as precipitation and temperature, by changing the mean and extremes for precipitation, evapotranspiration (ET), and runoff [2]. Stationarity of a variable implies that its probability density function is time invariant, because the natural system that gives rise to this variable fluctuates only within an unchanging envelop of variability [3,4]. Hitherto, most of the hydrological modeling, water resources management, infrastructural design, and operation processes have relied upon the fundamental assumption of stationarity of temperature and precipitation [5-8]. But the concept of stationarity has been compromised by anthropogenic interventions in the water basins, as well as by the effects of climate change. Therefore, it has become necessary to analyze the stationarity of climate data before using it for planning purposes.

One of major consequences of the loss of stationarity of climatic parameters is an increase in the uncertainty of those parameters [9]. Water vapor accounts for a very small portion $(0.25 \%)$ of the 
atmospheric constituents, but is an important regulator of global climate and weather patterns [10]. Increased surface temperature causes more ET of surface water, the process itself being facilitated by the increased water-carrying capacity of the atmosphere due to the elevated temperature [10]. This alteration of ET is expected to intensify the hydrological cycle with larger implications for ecosystem services [11]. At the same time a decrease in the total global land surface ET was observed due to the limitations of the moisture source itself [12]. Higher surface evapotranspiration leads to increased intensity and duration of drought. At the same time, the potential of atmospheric storms to carry moisture is elevated, which results in more precipitation events [13]. The variance of precipitation has been increasing globally with wet areas receiving more rainfall and dry areas becoming drier [14]. While the changes in rainfall amount and rainy days in India have not been significant [15], they have been decreasing in Italy [16] and increasing in China [17]. It has also been observed that the frequency of precipitation extremes and floods has increased significantly in Europe [18] and the United States (US), but not in Canada [19-21]. This increased uncertainty in weather and climatic patterns is going to have larger implications for the ecosystem services and other natural systems. It is worth noting that our ability to predict the climatic parameters, such as temperature and precipitation, with a comfortable level of confidence has already been hindered by great uncertainties that stem from our limited knowledge of physical and atmospheric processes [22].

Agriculture accounts for about $80 \%$ of the total global anthropogenic water use and is thus the largest single consumer of the fresh water [23]. Not all agricultural land has the insurance of a regular supply of water from an irrigation system, because irrigation-related withdrawals account for only $60 \%$ of freshwater withdrawals. The remaining agricultural land is dependent on precipitation for its water supply, which is a natural inheritor of uncertainty in the hydrological cycle and precipitation due to climate change. Crop yield is susceptible to both intense droughts and extreme precipitation events. While droughts create water stress in growing plants, excess water in the soil is detrimental for the plant health because it causes flooding and washes off the fertile topsoil [24,25]. Thus, neither excess water nor extended dry periods are suitable for plant growth. While irrigation protects plants from such extremes by ensuring a regular fulfillment of plants' water requirements at a scheduled interval, rain-fed agricultural systems are vulnerable to the vagaries of the atmospheric processes. Therefore, such rain-fed systems are expected to be hit hard by the impacts of climate change.

The Corn Belt of the US Midwest, comprised of roughly 11 states that straddle the Mississippi river, is an expanse that includes Ohio in the East to eastern Nebraska and South Dakota in the West. The Corn Belt contributes approximately $80 \%$ of the total corn production in the US and also accounts for $36 \%$ of the global corn production [26]. Despite the substantial contribution of the Corn Belt to the corn market, only $43 \%$ of the corn production area is irrigated [27]. While the states to the West of Mississippi River have well-developed irrigation systems, the states lying to the East of the river are mostly reliant on rain-fed systems [28]. Most of the agricultural land in the two largest corn-producing states of the US-Iowa and Illinois (in the same order) — get their plants' water supply almost entirely from precipitation. This dependence on a rain-fed system without any viable alternatives exposes the agriculture in these states to the uncertainty brought about by climate change. Therefore, it becomes necessary to analyze the climatic parameters, such as precipitation and temperature, especially in the recent past and the near future, in relation to the impacts of their variability and changes on the agricultural systems.

There have been numerous studies that have attempted to determine the impacts of climate change on precipitation patterns and temperatures from climatological and hydrological perspectives at global and regional scales [29-31]. Although there are few studies that have investigated how climate change might impact crop yield [32,33], to our knowledge, there have not been any studies that focus on the changing dynamics of the climate itself during the cropping season in the US Midwest. Furthermore, from the perspective of a corn farmer in Illinois whose only source of irrigation is natural precipitation, the snowfall of winter-despite its role in and contribution to the hydrological cycle and annual precipitation - is of less relevance than the amount and frequency of rainfall in the summer and 
early fall months that represent the corn growing period and thus directly impact corn productivity. This provides a strong rationale to study the characteristics and trends of precipitation at a temporal scale significant to corn farmers-the cropping season. Therefore, in this study, we have tried to identify the footprints of climate change on the precipitation of the state of Illinois and the dynamics of this change in relation to the cropping season.

\section{Materials and Methods}

\subsection{Study Area}

Illinois lies in the Midwestern United States, within $36^{\circ} 58^{\prime} \mathrm{N}$ to $42^{\circ} 30^{\prime} \mathrm{N}$ latitude and $87^{\circ} 30^{\prime} \mathrm{W}$ to $91^{\circ} 31^{\prime} \mathrm{W}$ longitude, with a total area of $149,998 \mathrm{~km}^{2}$. Illinois has a humid continental climate with four distinct seasons: winter (December-February), spring (March-May), summer (June-August), and fall (September-November). Summer is hot and humid, whereas winter is usually cold. Spring and fall have pleasant days with comfortable temperatures [34]. The weather condition is very unstable with fluctuations in temperature, humidity, wind speed, and direction.

Agriculture plays a huge role in Illinois' economy; rural Illinois depends on the economy generated from agricultural production, whereas urban Illinois profits from food processing industries and firms based on agriculture. With more than three-quarters of the state's land being used as farmland, Illinois is one of the biggest producers of corn and soybeans in the United States [35]. The increase in human population dictates that more food needs to be produced and constrained by the ever-diminishing area of the fertile land. With less than $5 \%$ of agricultural lands being irrigated, agriculture in Illinois depends primarily on rainfall. Thus, it is important to understand the properties and behavior of precipitation to ensure greater confidence in agricultural planning and its successful implementation.

Illinois is prone to extreme weather conditions and climatic hazards. The state experienced deadly heat waves in 1995 and 1999, which caused many human and economic losses in the area. Similarly, cold waves, blizzards, flash flooding, and rainstorms are common hazards in Illinois. Illinois faced unexpectedly warm winters in 1997-1998 due to El Niño. Serious droughts hit the state in 1930-1931, 1933-1934, and 1953-1954 due to inadequate precipitation [34]. The significant droughts in the 2000s include the drought of 2007 and the drought of 2012, which was the worst drought the state had experienced in recent history with statewide average precipitation at $713.7 \mathrm{~mm}$. It resulted in lower yields of corn and soybeans and impacted the livestock industry as well [36]. On the other hand, June of 2015 was the wettest month recorded in the last 100 years with $221.2 \mathrm{~mm}$ of rainfall; the normal rainfall for June in Illinois is $106.9 \mathrm{~mm}$ [37].

Daily precipitation data from 119 weather stations in Illinois, spatially distributed as shown in Figure 1, has been used in the study (the locations of these stations have been provided in the supplementary materials). Most of the data used was obtained from the United States Department of Agriculture's Agricultural Research Service (USDA ARS). This dataset provided by the USDA ARS is derived from the National Oceanic and Atmospheric Administration (NOAA) data, which includes Cooperative Observer Network (COOP) and Weather Bureau Army Navy (WBAN) stations. Climate data for some of the stations was obtained from the Midwestern Regional Climate Center (MRCC) database.

The stations used in this study were selected based on several criteria, which included length of the data, completeness, and the spatial distribution of the stations. Based on these criteria, 119 stations were chosen that had precipitation data from 1950 to 2010 with more than $90 \%$ coverage (i.e., $<10 \%$ missing data) and are distributed across the Illinois (station coverage 1 per $1260 \mathrm{~km}^{2}$ ). The data obtained from the USDA ARS was more than $99 \%$ complete as ARS fills in the missing data using an inverse distance weighted interpolation method. 


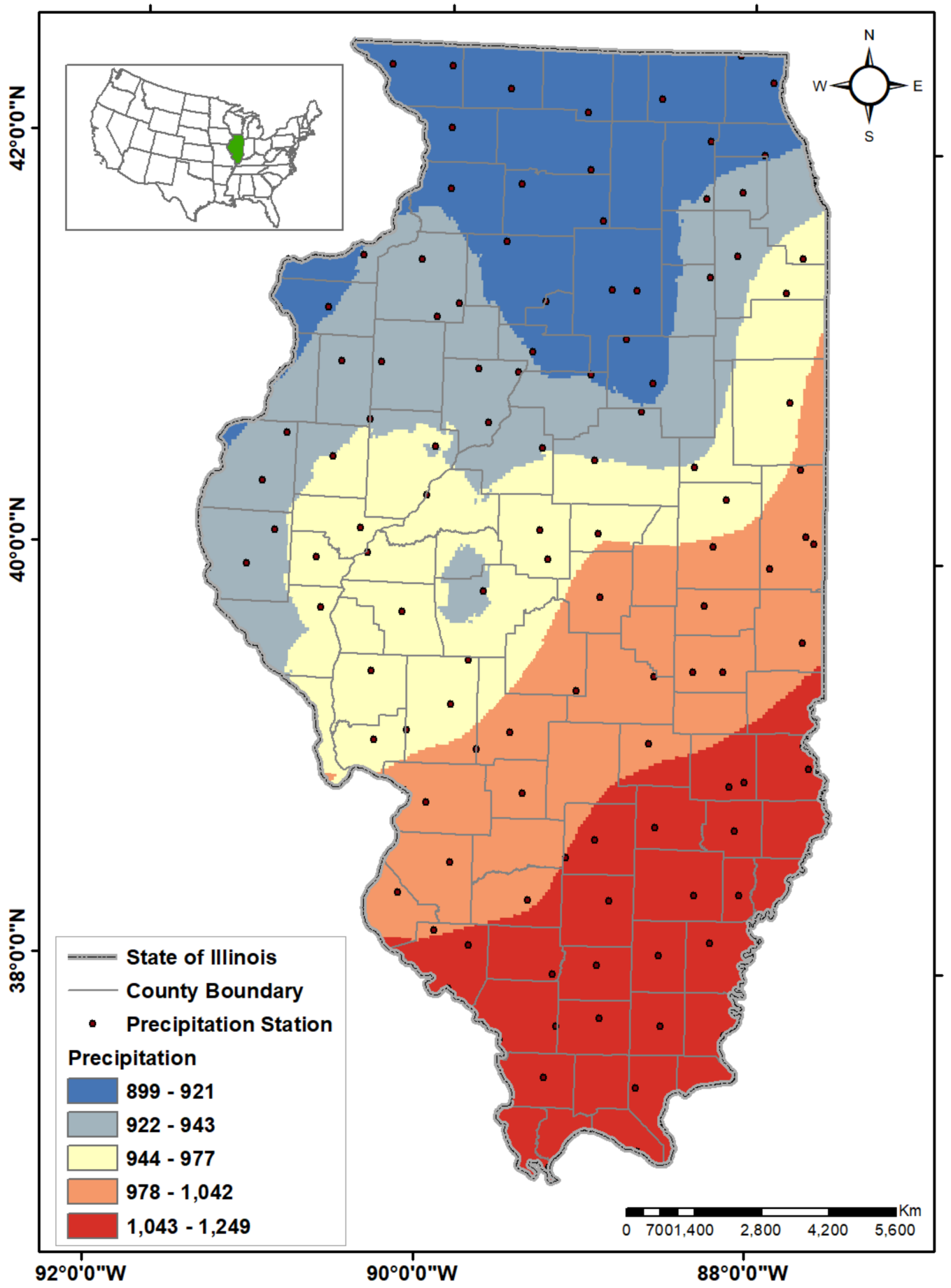

Figure 1. Location map showing the distribution of precipitation stations within the state of Illinois. The map also shows an interpolated distribution of long-term annual precipitation across the state. The heat-map represents the quantiles in rainfall at equal intervals

\subsection{Trend Analysis}

Various parametric and nonparametric statistical methods have been developed for determining trends in a time series. The Mann-Kendall (MK) test is one of the frequently used methods for testing trends in precipitation data [38-42]. Unlike regression analysis, which requires the data series to be normally distributed, the MK test does not require the underlying data to follow a specific linear distribution or the trend, if at all. The only underlying assumption of the MK test is that when no trend 
is present, the data is independent and identically distributed. The test procedure is also capable of dealing with missing data, which is a common occurrence in precipitation data series. Due to these properties of the MK test, it has been reported by the World Meteorological Organization (WMO) for climate change analysis [43]. Because the MK test does not give the magnitude of the trend, the Theil-Sen Slope Estimator (also nonparametric) has been used to obtain the magnitude in this study. The Theil-Sen approach (TS) has been found to give a better estimate of the slope than that obtained from the ordinary least-square regression model. The MK test and TS methods have been widely used to test the stationarity, or lack thereof, in climatic time series [44-50].

\subsubsection{Mann-Kendall Trend Test}

The MK trend test is a nonparametric procedure for statistically assessing the monotonic trends in the variable of interest over time. The null $\left(H_{0}\right)$ and alternative $\left(H_{a}\right)$ hypotheses for the MK test, used in this study, are as follows:

$H_{0}$ : No monotonic trend is present;

$H_{a}$ : Monotonic trend is present.

The test statistic $S$ is given by:

$$
S=\sum_{i=1}^{n-1} \sum_{j=i+1}^{n} \operatorname{sgn}\left(x_{j}-x_{i}\right)
$$

where $n$ is the number of data points, $x_{i}$ and $x_{j}$ are data values in time series at time $i$ and $j$, respectively $(j>i)$, and $\operatorname{sgn}\left(x_{j}-x_{i}\right)$. is the sign function given by:

$$
\operatorname{sgn}\left(x_{j}-x_{i}\right)=\left\{\begin{array}{c}
-1 \text { for }\left(x_{j}-x_{i}\right)<0 \\
0 \text { for }\left(x_{j}-x_{i}\right)=0 \\
+1 \text { for }\left(x_{j}-x_{i}\right)>0
\end{array}\right.
$$

The variance of the statistic is given by:

$$
\operatorname{Var}(S)=\frac{n(n-1)(2 n+5)-\sum_{p=1}^{q} t_{p}\left(t_{p}-1\right)\left(2 t_{p}+5\right)}{18}
$$

where $t_{p}$ is the number of ties for $p$ th value and $q$ is the number of tied values.

For sample size $n>10$, the standard test statistic $Z$ is given as:

$$
Z=\left\{\begin{array}{c}
\frac{S-1}{\sqrt{V(S)}}, \text { if } S>0 \\
0, \text { if } S=0 \\
\frac{S+1}{\sqrt{V(S)}}, \text { if } S<0
\end{array}\right.
$$

\subsubsection{Theil-Sen Slope Estimator}

The Theil-Sen slope estimator is a nonparametric approach to quantify the slope of the trend in a time series, given as:

$$
Q_{i}=\frac{x_{j}-x_{k}}{j-k} \text { for } i=1, \ldots, N
$$

where $Q_{i}$ is Sen's slope, $x_{j}$ and $x_{k}$ are data values of the same observational unit at time $j$ and $k$, respectively $(j>k)$.

If the time period has only one datum, then $N=n(n-1) / 2$, where $n$ is the number of time periods. 
The total $N$ values of $Q_{i}$ are ranked in ascending order, and the median of Sen's slope is calculated as:

$$
Q_{\text {med }}=\left\{\begin{array}{c}
Q_{(N+1) / 2}, \text { if } N \text { is odd } \\
\frac{Q_{N / 2}+Q_{(N+2) / 2},}{2}, \text { if } N \text { is even }
\end{array}\right.
$$

The sign of $Q_{\text {med }}$ reflects the data trend direction, whereas its value gives the magnitude of slope of the trend.

\section{Results}

\subsection{Long-Term Properties of Precipitation}

Based on this analysis, the state of Illinois receives an annual precipitation of $1061 \mathrm{~mm}$. The value is obtained as an area-weighted average of the long-term average annual station precipitation. The spatial distribution of the long-term annual precipitation for the state has been presented in Figure 1. The southern part of the state receives more precipitation than the northern part. Whiteside County, located at the Northwest of the state, receives a minimum annual precipitation of $863 \mathrm{~mm}$, and Alexander County, located in the southern extreme of the state, receives a maximum precipitation of $1244 \mathrm{~mm}$. The number of annual rainy days is seen to increase from West to East. Maximum and minimum annual rainfall days for the study region was found to be 82 and 171, respectively. For most of the stations, rainfall days varied from 88 to 130, with higher rainfall days observed only by 6 stations.

The monthly distribution of the annual precipitation has been presented in Figure 2a. While the precipitation distribution is fairly uniform throughout the year, spring and summer receive more rainfall than autumn and winter. The summer months receive the highest amount of precipitation; as for the three months of May-July, the precipitation exceeds the threshold of $100 \mathrm{~mm}$, with a maximum precipitation of $107.5 \mathrm{~mm}$ in the month of May. The months of January and February receive precipitation lower than $60 \mathrm{~mm}$, with the precipitation being confined to $50 \mathrm{~mm}$ in February. On average, Illinois receives precipitation for 109 days a year. The monthly distribution of rainy days has been shown in Figure 2b. The months of April, May, and June receive rainfall for more than 10 days. February and September receive rainfall for less than 8 days. In Figure 2c, the annual time series of the precipitation for the region has been shown. The time series is accompanied by the plot for the standard error for each year. The standard error is obtained by dividing the standard deviation for each year (obtained from the annual precipitation of all 119 stations) by the square root of the total number of stations. The annual precipitation was found to increase at the rate of $1.84 \mathrm{~mm} /$ year, and statistically the slope was not found to be significant. The insignificance of the precipitation change is also underscored by the flatness of the overlapping line for the 10-year moving average. 

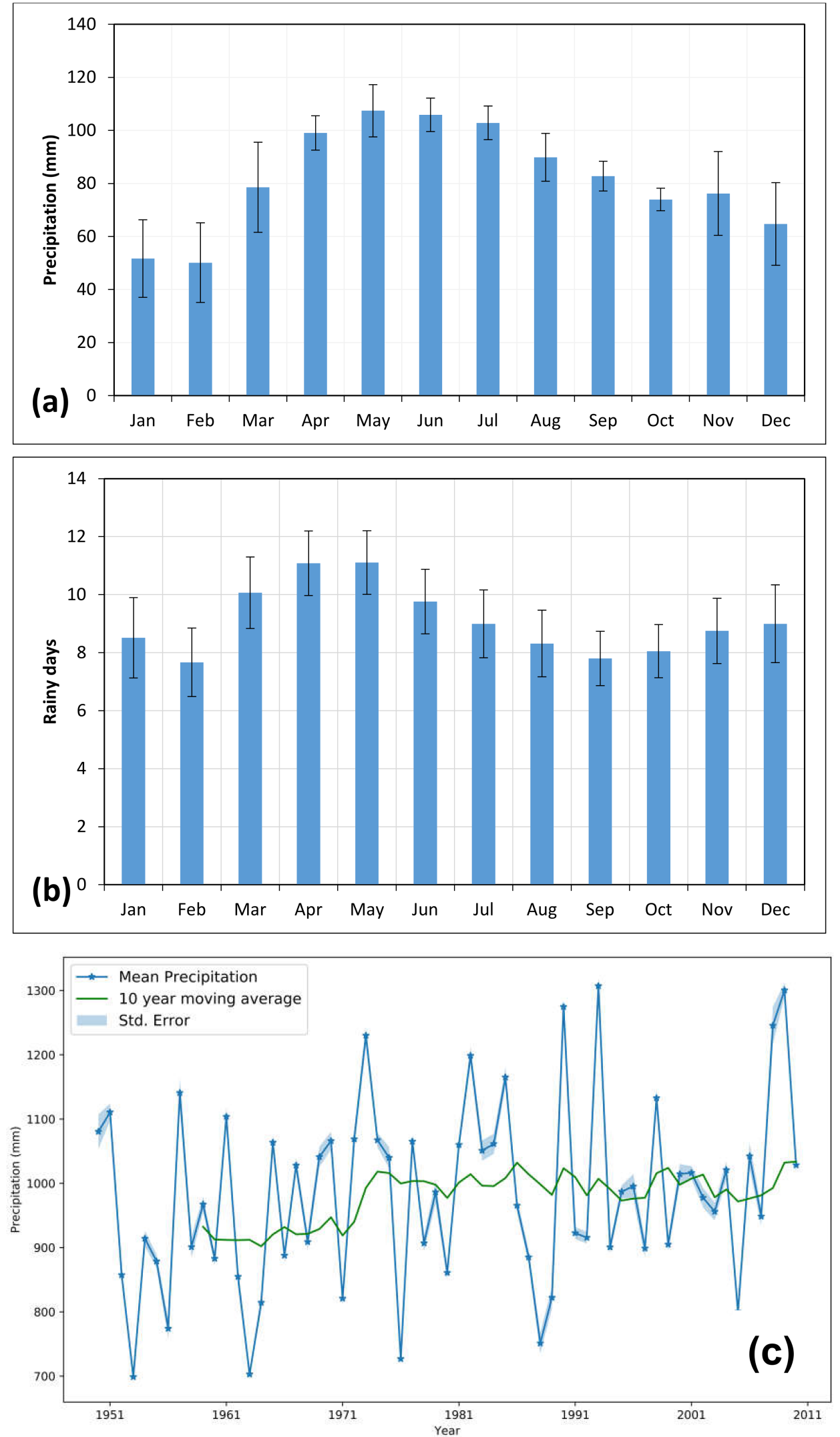

Figure 2. (a) Long-term monthly distribution of the area-weighted precipitation amounts, (b) monthly distribution of the total number of rainy days for the area-weighted precipitation, and (c) spatially averaged precipitation time series of the study area along with the standard error and 10-year moving average. 


\subsection{Trends in Annual and Seasonal Precipitation}

Because it is difficult to glean useful information about long-term trends in precipitation from the data on a daily scale, the time series was aggregated into an annual scale. Because the measurement of precipitation is volumetric, the average annual value of precipitation for a year is the sum of the daily values for that year. The result of the analysis at the annual scale has been presented in Figure 3 . Out of the 119 stations used in the analysis, it was observed that 114 stations recorded increasing precipitation over the study period. Of those 114 stations, the positive trend was statistically significant for 51 stations $(\sim 40 \%)$. This shows that, on average, precipitation is increasing over Illinois. The trend of the total number of rainy days in a year was also computed. It was observed that 89 stations showed an increasing trend of annual rainy days with the trend being significant in 48 stations. Of the remaining 30 stations, which had decreasing numbers of annual rainy days, the trend was significant in only two stations. With the changing climate, it is expected that extreme precipitation events are going to be more frequent. With the analysis of extreme precipitation events, defined as a daily precipitation value that is greater than the 90th percentile value of the observed precipitation data for the station, it was found that the number of occurrences of extreme precipitation events is also increasing. An overwhelming 109 stations experienced an increase in extreme precipitation events. Of those 109 stations, the increase was found to be significant in 45 stations.
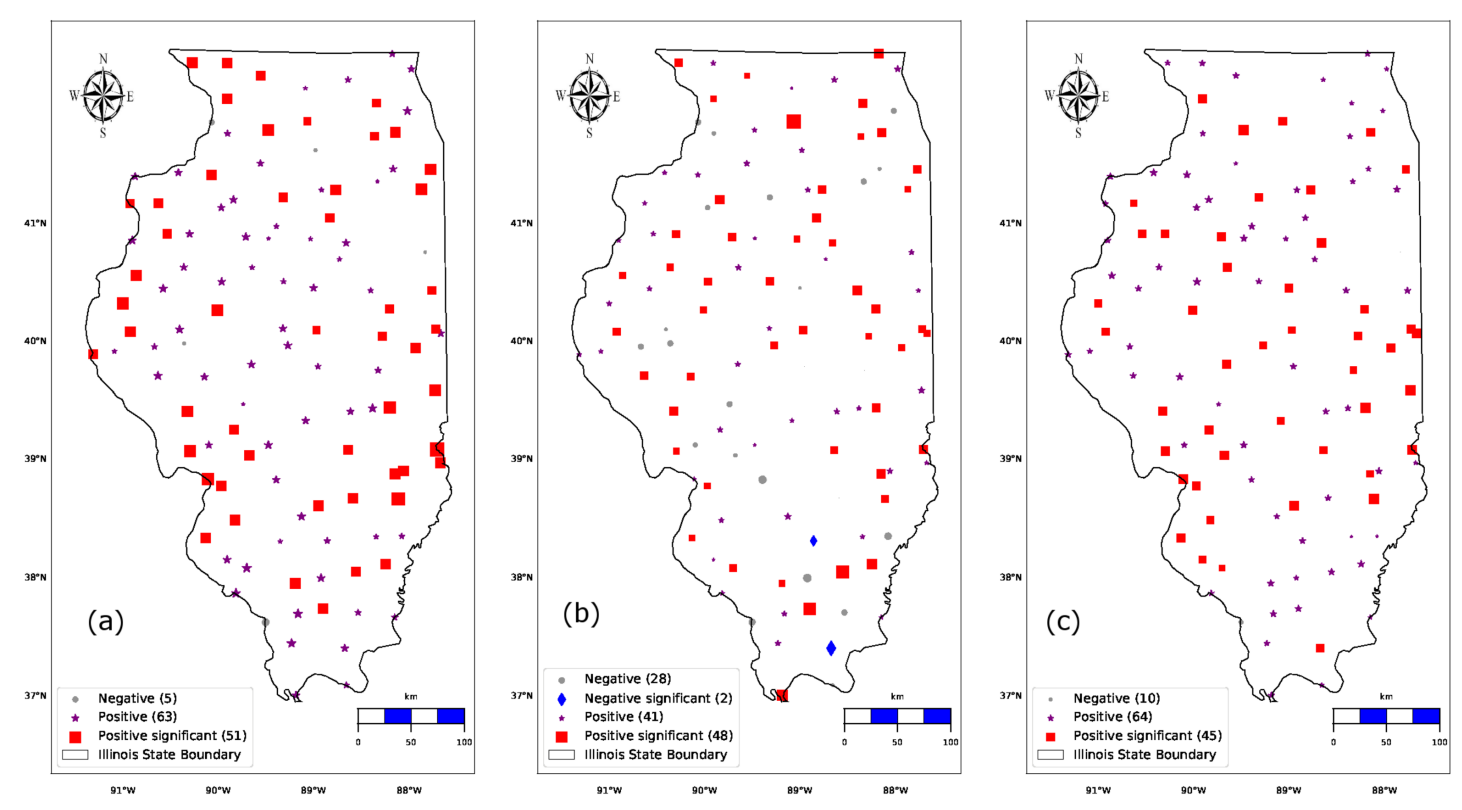

Figure 3. Distribution of trends in the annual precipitation parameters: (a) annual rainfall, (b) annual rainy days, and (c) number of days when rainfall is higher than the 90th percentile. In all the figures, the marker sizes have been scaled to represent the magnitude of the Theil-Sen slope.

Following the analysis at an annual level, this study also investigated precipitation trends at a seasonal level. Illinois is characterized by four distinct seasons-spring (March, April, May), summer (June, July, August), fall (September, October, November), and winter (December, January, February). The result of the analysis has been presented in Table 1 . The positive and negative signs correspond to increasing and decreasing trends, respectively, and the figures inside the parenthesis represent the number of stations with statistically significant trends. Delving into the seasonal level provides us an opportunity to comprehend the within-year distribution of the change. It can be inferred from Table 1 that most of the change that we observed earlier in the annual data is concentrated in the fall. It can also be seen that the summer, during which the crop is growing and requires most of the water for its physiological activities, has not changed significantly. 
Table 1. Trend statistics for the seasonal precipitation parameters. (' + ' sign indicates a positive trend and ' - ' sign indicates a negative trend. Values outside of the parenthesis (and in boldface) indicate the number of stations with a significant trend and values inside the parenthesis indicate the number of stations without a significant trend).

\begin{tabular}{ccccc}
\hline Parameter & Spring & Summer & Fall & Winter \\
\hline \multirow{2}{*}{ Annual Rainfall } & $+7(+91)$ & $+5(+81)$ & $+61(+55)$ & $+18(+74)$ \\
& $-0(-5)$ & $-1(-32)$ & $-0(-3)$ & $-0(-27)$ \\
Rainy Days & $+8(+32)$ & $+33(+38)$ & $+42(+53)$ & $+17(+30)$ \\
Extreme & $-7(-72)$ & $-4(-44)$ & $-0(-24)$ & $-7(-65)$ \\
Precipitation & $+10(+28)$ & $+9(+28)$ & $+74(+34)$ & $+12(+9)$ \\
\hline
\end{tabular}

\subsection{Trends in Precipitation during the Cropping Season}

In this study, the period in each year starting from April 15 and ending on October 15 was designated as the cropping season. The USDA reports the earliest planting date and the latest harvesting date for each county of Illinois [51]. The period adopted here adds a tolerance buffer of 15 days on either end of that reported period. The results for the two major parameters has been shown in Figure 4, and the results for the rest of the parameters have been displayed in Table 2. While it was observed that there is a general pattern of increasing precipitation during the cropping period with a positive trend being observed in 101 stations, only 16 of the 101 stations had a significant increase. It was also observed that among the 83 stations showing an increase in the number of rainy days, the trend was significant in only 33 stations. Of the remaining 36 stations, the number of rainy days had reduced significantly in five stations only. In this study, we also analyzed the trends of consecutive rainy days and consecutive dry days. For this purpose, a period of five or more consecutive dry days was considered to be a dry period, and a period of three or more consecutive wet days was considered to be a wet period. An important parameter of interest is the average number of days in dry period (along with the analogous parameter for the wet period). It was observed that neither the wet nor dry periods had experienced any significant trend in the average number of days.

Table 2. Trend statistics for the precipitation parameters during the cropping season. Format of the results: stations with a significant trend (stations with significant trend as a percentage of the total number of stations\} (stations with an insignificant trend).

\begin{tabular}{ccc}
\hline Precipitation Parameters & Stations with Positive Trend & Stations with Negative Trend \\
\hline Annual Sum & $\mathbf{1 6}\{13\}(85)$ & $\mathbf{1}\{1\}(17)$ \\
Rainy Days & $\mathbf{3 6}\{30\}(47)$ & $\mathbf{5}\{4\}(31)$ \\
Dry Days Average & $\mathbf{2}\{1.7\}(41)$ & $\mathbf{3}\{2.5\}(73)$ \\
Wet Days Average & $\mathbf{1 6}\{13.5\}(36)$ & $\mathbf{1 1}\{9\}(66)$ \\
Dry Period Frequency & $\mathbf{4}\{3\}(4)$ & $\mathbf{3}\{2.5\}(108)$ \\
Wet Period Frequency & $\mathbf{0}\{0\}(24)$ & $\mathbf{5}\{4\}(90)$ \\
\hline
\end{tabular}



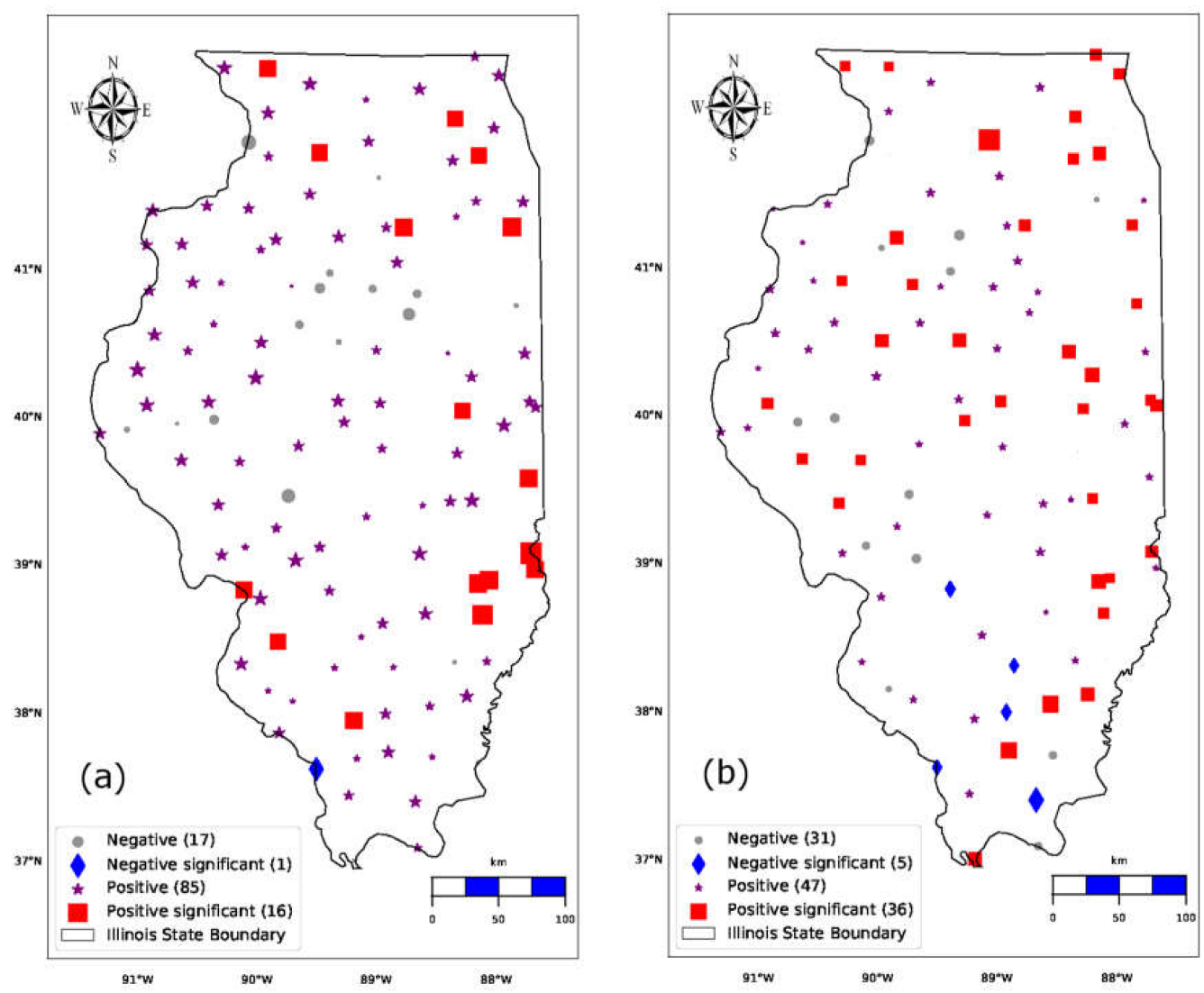

Figure 4. Distribution of trends in the precipitation parameters during the cropping season: (a) cumulative rainfall and (b) number of rainy days. In all the figures, the marker sizes have been scaled to represent the magnitude of the Theil-Sen slope.

\section{Discussion}

It can be inferred from the results that the annual precipitation in Illinois has been increasing slightly based on the analysis of 60 years of precipitation data. While the trend is statistically significant in less than $50 \%$ of the observed stations, the annual precipitation in most of the stations shows an upward movement temporally. Spatially, this increasing precipitation did not follow any discernable pattern, even though we can see that the density of the stations with significant trends is slightly higher in the northern and central regions of the state than in the southern region. Thus, it would be safe to infer that the stations with significant amounts of increasing precipitation are distributed randomly across the state, without any salient spatial pattern. It can be also be further inferred from this random spatial distribution that the causal factors for such increases in precipitation have impacted the whole state almost uniformly. A study found that very few stations in the coterminous US exhibited trends in precipitation amounts and frequency, and any changes, when present, were concentrated within limited areas, pointing towards localized effects. The study, carried out by [38], showed that most of the change was concentrated in the eastern and Midwestern states. Their study also showed that there are a reasonable number of stations with significant, positive trends in the northern and central regions of Illinois, thereby supporting the finding of this study. This increase in precipitation can be attributed to two sources. First of all, we saw that the number of rainy days has increased. This implies that the frequency of precipitation events has increased. Secondly, the extreme precipitation events (described as precipitation in the upper 10 percentiles of the data) have also increased in the state. Thus, we have had an increase in both the intensity and frequency of precipitation, and these two factors have contributed to the increasing precipitation amounts in tandem. An analysis of the precipitation data for the coterminous US since 1910 also produced similar conclusions [30]. They found that precipitation 
has increased by $10 \%$ over the contiguous US, and they also attributed that increase in precipitation to the increase in frequency and intensity of the rainfall.

On further refining the temporal scale to the seasonal level, it was observed that most of the change in precipitation is concentrated in the fall. While we saw a general increase in precipitation in all the seasons, the increase was significant for most of the stations in the fall only. This is in contrast to the finding of [38], in which the researchers found that in Illinois, the majority of the change is concentrated within the winter and summer months. Because the number of stations considered in this study is much higher than that considered by the aforementioned study, we assert a higher degree of confidence in our findings. A study carried out by [52] found that precipitation in the fall has been increasing gradually since the 1980s in Illinois and Indiana, and this finding further bolsters our results. That said, the scope of this study is limited to the statistical analysis of the time series of historical precipitation data, and data analytics alone is insufficient to understand the seasonal pattern of such change. Indeed, further analysis warrants hydro-climatological analysis.

While annual and seasonal scales are informative from the perspective of water managers, the most relevant period for the farmers of Illinois is the cropping period. The author of [52] found that Midwestern precipitation changes have slowed down the corn yield. This study demonstrated that while precipitation has increased over the cropping period, it has not increased significantly. Nonetheless, we saw some increase in frequency of rainy days during this period. Increased frequency of precipitation ensures regular supplies of water for growing plants and is therefore a good outcome from an agricultural perspective. Another important factor that can affect the crop yield is the duration and frequency of wet and dry periods. A simulation study was carried out to determine the effects of excess precipitation from climate change on US crops and the study concluded that corn production losses may double under increased moisture conditions and thus cause an estimated loss of $\$ 3$ billion per annum [24]. On the other hand, a field study to determine the effects of water stress found that water stress reduces crop yields significantly [25]. It was observed that while there has been a slight increase in the frequency of wet periods, there has not been much increase in the frequency of dry periods. It was also worth noting that there has not been any significant change in the average number of days in the dry or wet periods. While various studies have suggested an increase in the intensity and frequency of droughts under global warming [31], the precipitation pattern of Illinois is yet to exhibit any signs of such anticipated intensification of dry periods.

It can be concluded from the results presented above that the vulnerability of the crops to extreme climate events has not increased in Illinois. These results seem to contradict the anticipated effects of climate change and fail to compromise the concept of stationarity as is widely predicted (as discussed in the Introduction). But it is worth remembering here that most of the hypotheses, findings, and conclusions addressing the issues of climate change and the stationarity of climatic parameters have been formulated at a global scale, and despite its global agricultural significance, the local determinants of the climate of Illinois may be strong enough to offset the global effects as they currently stand. Therefore, the findings of this study should not be interpreted as a rejection of the impacts of global climate change and the subsequent loss of stationarity. It is recommended that this study be interpreted as a welcome finding for the state that prides itself as the second largest producer of corn in the US.

\section{Conclusions}

This study focused on determining the long-term properties of precipitation patterns in Illinois using precipitation time series data from 119 spatially distributed stations around the state. Long-term trends in precipitation were also analyzed to determine the effects of global warming and climate change. It was observed that the precipitation amounts in Illinois have increased slightly over the past 60 years and that increase can be attributed to the increase in frequency of both average rainfall and extreme precipitation events. While most of the seasons show a trend of increasing precipitation amounts, most of the increase is concentrated on the fall. Thus, this increase in precipitation has 
not been advantageous from the agricultural perspective because most of the increase is occurring outside of the cropping period. But, nevertheless, both droughts and intense rainfall events have not become more frequent in the cropping period, as expected from the findings of other climate studies, and this provides a silver lining for long-term agricultural prospects in Illinois. This study concentrated mostly on the analysis of time series data to identify the signatures of climate change on precipitation levels. One of the findings of this study - the intensification of precipitation during the fall—cannot be explained by the data alone. Therefore, it would be interesting to explore the climatological reasons for such behavior of fall precipitation, and thus, this could be a path forward to extending this study.

Supplementary Materials: The following are available online at http:/ /www.mdpi.com/2073-4441/10/4/433/s1.

Acknowledgments: This work was supported by the USDA National Institute of Food and Agriculture, Hatch project ILLU-741-379.

Author Contributions: V.D. and R.B. conceived of and designed the methodology; S.G. collected and cleaned the data; V.D. carried out the coding and analysis; V.D. and S.G. wrote the paper; R.B. supervised the whole project.

Conflicts of Interest: The authors declare no conflict of interest.

\section{References}

1. Pachauri, R.K.; Allen, M.R.; Barros, V.R.; Broome, J.; Cramer, W.; Christ, R.; Church, J.A.; Clarke, L.; Dahe, Q.; Dasgupta, P. Climate Change 2014: Synthesis Report. Contribution of Working Groups I, II and III to the Fifth Assessment Report of the Intergovernmental Panel on Climate Change; IPCC: Geneva, Switzerland, 2014.

2. McCarl, B.A.; Villavicencio, X.; Wu, X. Climate change and future analysis: Is stationarity dying? Am. J. Agric. Econ. 2008, 90, 1241-1247. [CrossRef]

3. Milly, P.C.; Betancourt, J.; Falkenmark, M.; Hirsch, R.M.; Kundzewicz, Z.W.; Lettenmaier, D.P.; Stouffer, R.J.; Dettinger, M.D.; Krysanova, V. On critiques of "Stationarity is dead: Whither water management?" Water Resour. Res. 2015, 9, 7785-7789.

4. Luce, C.; Abatzoglou, J.; Holden, Z. Declining streamflows reveal nonstationary orographic precipitation enhancement driven by reduced westerly flows. In Proceeding of the EGU General Assembly 2016, Vienna, Austria, 17-22 April 2016; Volume 18, p. 10309.

5. Chen, H.-L.; Rao, A.R. Testing Hydrologic Time Series for Stationarity. J. Hydrol. Eng. 2002, 7, 129-136. [CrossRef]

6. Vaze, J.; Post, D.A.; Chiew, F.H.S.; Perraud, J.-M.; Viney, N.R.; Teng, J. Climate non-stationarity —Validity of calibrated rainfall-runoff models for use in climate change studies. J. Hydrol. 2010, 394, 447-457. [CrossRef]

7. Chinnasamy, P.; Bharati, L.; Bhattarai, U.; Khadka, A.; Dahal, V.; Wahid, S. Impact of planned water resource development on current and future water demand in the Koshi River basin, Nepal. Water Int. 2015, 40, 1004-1020. [CrossRef]

8. Dahal, V.; Shakya, N.M.; Bhattarai, R. Estimating the Impact of Climate Change on Water Availability in Bagmati Basin, Nepal. Environ. Process. 2016, 3, 1-17. [CrossRef]

9. Milly, P.C.D.; Betancourt, J.; Falkenmark, M.; Hirsch, R.M.; Kundzewicz, Z.W.; Lettenmaier, D.P.; Stouffer, R.J. Stationarity is dead: Whither water management? Science 2008, 319, 573-574. [CrossRef] [PubMed]

10. Gimeno, L.; Stohl, A.; Trigo, R.M.; Dominguez, F.; Yoshimura, K.; Yu, L.; Drumond, A.; Durn-Quesada, A.M.; Nieto, R. Oceanic and terrestrial sources of continental precipitation. Rev. Geophys. 2012, 50. [CrossRef]

11. Vörösmarty, C.J.; McIntyre, P.B.; Gessner, M.O.; Dudgeon, D.; Prusevich, A.; Green, P.; Glidden, S.; Bunn, S.E.; Sullivan, C.A.; Liermann, C.R.; Davies, P.M. Global threats to human water security and river biodiversity. Nature 2010, 467, 555-561. [CrossRef] [PubMed]

12. Jung, M.; Reichstein, M.; Ciais, P.; Seneviratne, S.I.; Sheffield, J.; Goulden, M.L.; Bonan, G.; Cescatti, A.; Chen, J.; de Jeu, R.; et al. Recent decline in the global land evapotranspiration trend due to limited moisture supply. Nature 2010, 467, 951-954. [CrossRef] [PubMed]

13. Trenberth, K.E. Changes in precipitation with climate change. Clim. Res. 2011, 47, 123-138. [CrossRef]

14. Dore, M.H.I. Climate change and changes in global precipitation patterns: What do we know? Environ. Int. 2005, 31, 1167-1181. [CrossRef] [PubMed]

15. Jain, S.K.; Kumar, V. Trend analysis of rainfall and temperature data for India. Curr. Sci. 2012, 102, 37-49. 
16. Longobardi, A.; Villani, P. Trend analysis of annual and seasonal rainfall time series in the Mediterranean area. Int. J. Climatol. 2009, 30. [CrossRef]

17. Gemmer, M.; Becker, S.; Jiang, T. Observed monthly precipitation trends in China 1951-2002. Theor. Appl. Climatol. 2004, 77, 39-45. [CrossRef]

18. Madsen, H.; Lawrence, D.; Lang, M.; Martinkova, M.; Kjeldsen, T.R. Review of trend analysis and climate change projections of extreme precipitation and floods in Europe. J. Hydrol. 2014, 519, 3634-3650. [CrossRef]

19. Kunkel, K.E. North American Trends in Extreme Precipitation. Nat. Hazards 2003, 29, 291-305. [CrossRef]

20. Kunkel, K.E.; Andsager, K.; Easterling, D.R.; Kunkel, K.E.; Andsager, K.; Easterling, D.R. Long-Term Trends in Extreme Precipitation Events over the Conterminous United States and Canada. J. Clim. 1999, 12, 2515-2527. [CrossRef]

21. Prein, A.F.; Rasmussen, R.M.; Ikeda, K.; Liu, C.; Clark, M.P.; Holland, G.J. The future intensification of hourly precipitation extremes. Nat. Clim. Chang. 2017, 7, 48-52. [CrossRef]

22. Lobell, D.B.; Burke, M.B. Why are agricultural impacts of climate change so uncertain? The importance of temperature relative to precipitation. Environ. Res. Lett. 2008, 3, 34007. [CrossRef]

23. Wallace, J. Increasing agricultural water use efficiency to meet future food production. Agric. Ecosyst. Environ. 2000, 82, 105-119. [CrossRef]

24. Rosenzweig, C.; Tubiello, F.N.; Goldberg, R.; Mills, E.; Bloomfield, J. Increased crop damage in the US from excess precipitation under climate change. Glob. Environ. Chang. 2002, 12, 197-202. [CrossRef]

25. Earl, H.J.; Davis, R.F. Effect of Drought Stress on Leaf and Whole Canopy Radiation Use Efficiency and Yield of Maize. Agron. J. 2003, 95, 688-696. [CrossRef]

26. Hayes, M.J.; Decker, W.L. Using NOAA AVHRR data to estimate maize production in the United States Corn Belt. Int. J. Remote Sens. 1996, 17, 3189-3200. [CrossRef]

27. Grassini, P.; Thorburn, J.; Burr, C.; Cassman, K.G. High-yield irrigated maize in the Western U.S. Corn Belt: I. On-farm yield, yield potential, and impact of agronomic practices. Field Crops Res. 2011, 120, 142-150. [CrossRef]

28. Grassini, P.; Yang, H.; Cassman, K.G. Limits to maize productivity in Western Corn-Belt: A simulation analysis for fully irrigated and rainfed conditions. Agric. For. Meteorol. 2009, 149, 1254-1265. [CrossRef]

29. Sayemuzzaman, M.; Jha, M.K.; Mekonnen, A. Spatio-temporal long-term (1950-2009) temperature trend analysis in North Carolina, United States. Theor. Appl. Climatol. 2014, 120, 159-171. [CrossRef]

30. Karl, T.R.; Knight, R.W. Secular Trends of Precipitation Amount, Frequency, and Intensity in the United States. Bull. Am. Meteorol. Soc. 1998, 79, 231-241. [CrossRef]

31. Dai, A. Increasing drought under global warming in observations and models. Nat. Clim. Chang. 2013, 3, 52-58. [CrossRef]

32. Challinor, A.J.; Watson, J.; Lobell, D.B.; Howden, S.M.; Smith, D.R.; Chhetri, N. A meta-analysis of crop yield under climate change and adaptation. Nat. Clim. Chang. 2014, 4, 287-291. [CrossRef]

33. Schlenker, W.; Roberts, M.J. Nonlinear temperature effects indicate severe damages to U.S. crop yields under climate change. Proc. Natl. Acad. Sci. USA 2009, 106, 15594-15598. [CrossRef] [PubMed]

34. Changnon, S.A.; Angel, J.R.; Kunkel, K.E.; Lehmann, C.M.B. Climate Atlas of Illinois; Illinois State Water Survey: Champaign, IL, USA, 2004.

35. Illinois Department of Agriculture Facts About Illinois Agriculture. Available online: https://www.agr.state. il.us/facts-about-illinois-agriculture/ (accessed on 12 November 2015).

36. Illinois Department of Natural Resources. The Drought of 2012. 2013. Available online: https:/ /www.isws. illinois.edu/hilites/drought/archive/2012/docs/TheDroughtOf2012.pdf (accessed on 12 November 2015).

37. Cli-Mate Midwest Regional Climate Center. Available online: http://mrcc.illinois.edu/CLIMATE (accessed on 9 November 2017).

38. Martino, G.; De Fontana, N.; Marini, G.; Singh, V.P. Variability and trend in seasonal precipitation in the continental United States. J. Hydrol. Eng. 2012, 18, 630-640. [CrossRef]

39. Nalley, D.; Adamowski, J.; Khalil, B.; Ozga-Zielinski, B. Trend detection in surface air temperature in Ontario and Quebec, Canada during 1967-2006 using the discrete wavelet transform. Atmos. Res. 2013, 132, 375-398. [CrossRef]

40. Sayemuzzaman, M.; Jha, M.K.; Mekonnen, A.; Schimmel, K.A. Subseasonal climate variability for North Carolina, United States. Atmos. Res. 2014, 145, 69-79. [CrossRef] 
41. Sonali, P.; Kumar, D.N. Review of trend detection methods and their application to detect temperature changes in India. J. Hydrol. 2013, 476, 212-227. [CrossRef]

42. Su, B.D.; Jiang, T.; Jin, W.B. Recent trends in observed temperature and precipitation extremes in the Yangtze River basin, China. Theor. Appl. Climatol. 2006, 83, 139-151. [CrossRef]

43. World Meteorological Organization (WMO). Climate Change, WMO Technical Note, No. 79; Secretariat of the World Meteorological Organization (WMO) Press: Geneva, Switzerland, 1966.

44. Gajbhiye, S.; Meshram, C.; Singh, S.K.; Srivastava, P.K.; Islam, T. Precipitation trend analysis of Sindh River basin, India, from 102-year record (1901-2002). Atmos. Sci. Lett. 2016, 17, 71-77. [CrossRef]

45. Gocic, M.; Trajkovic, S. Analysis of changes in meteorological variables using Mann-Kendall and Sen's slope estimator statistical tests in Serbia. Glob. Planet. Chang. 2013, 100, 172-182. [CrossRef]

46. Shadmani, M.; Marofi, S.; Roknian, M. Trend Analysis in Reference Evapotranspiration Using Mann-Kendall and Spearman's Rho Tests in Arid Regions of Iran. Water Res. Manag. 2012, 26, 211-224. [CrossRef]

47. Valdes-Abellan, J.; Pardo, M.A.; Tenza-Abril, A.J. Observed precipitation trend changes in the western Mediterranean region. Int. J. Climatol. 2017. [CrossRef]

48. Westra, S.; Alexander, L.V.; Zwiers, F.W. Global Increasing Trends in Annual Maximum Daily Precipitation. J. Clim. 2013, 26, 3904-3918. [CrossRef]

49. Xu, Z.X.; Takeuchi, K.; Ishidaira, H. Correlation between El Niño-Southern Oscillation(ENSO) and precipitation in South-east Asia and the Pacific region. Hydrol. Process. 2004, 18, 107-123. [CrossRef]

50. Zhang, Q.; Xu, C.Y.; Zhang, Z.; Chen, Y.D.; Liu, C.L. Spatial and temporal variability of precipitation over China, 1951-2005. Theor. Appl. Climatol. 2009, 95, 53-68. [CrossRef]

51. USDA-NASS NASS Reports by Year, United States Department of Agriculture, National Agricultural Statistics Service. Available online: https:/ / www.nass.usda.gov/Publications/Reports_By_Date/index.php (accessed on 5 November 2017).

52. Ge, Y. Detecting Climate Change and Its Impacts on Crop Yield in the Continental United States; University of Illinois at Urbana-Champaign: Champaign, IL, USA, 2012.

(C) 2018 by the authors. Licensee MDPI, Basel, Switzerland. This article is an open access article distributed under the terms and conditions of the Creative Commons Attribution (CC BY) license (http:/ / creativecommons.org/licenses/by/4.0/). 